\title{
Patching the glia reveals the functional organisation of the brain
}

\author{
Alexei Verkhratsky \\ Received: 15 April 2006 / Accepted: 28 April 2006 / Published online: 15 June 2006 \\ (C) Springer-Verlag 2006
}

\begin{abstract}
The neuroglia was initially conceived by Rudolf Virchow as a non-cellular connective tissue holding neurones together. In 1894, Carl Ludwig Schleich proposed a hypothesis of fully integrated and interconnected neuronalglial circuits as a substrate for brain function. This hypothesis received direct experimental support only hundred years later, after several physiological techniques, and most notably the patch-clamp method, were applied to glial cells. These experiments have demonstrated the existence of active and bi-directional neuronal-glial communications, integrating neuronal networks and glial syncytium into one functional circuit. The data accumulated during last 15 years prompt rethinking of the neuronal doctrine towards more inclusive concept, which regards both neurones and glia as equally responsible for information processing in the brain.
\end{abstract}

Keywords Glia · Neuronal-glial interactions · Ion currents · Neurotransmitter receptors $\cdot$ Calcium signalling

Patch-clamp $\cdot$ History

\section{The birth of glia}

The history of glial research is confusing and painful. For a good part of the 20th century, glial cells were very much neglected by neurobiology, and the real advance of glial physiology begun only in the mid-1980s. Yet, the concept of glia appeared almost 50 years before the neuronal doctrine of nervous system organisation was conceived,

\footnotetext{
A. Verkhratsky $(\square)$

Faculty of Life Sciences, The University of Manchester,

1.124 Stopford Building, Oxford Road,

Manchester M13 9PT, UK

e-mail: alex.verkhratsky@manchester.ac.uk
}

and by the end of 19th century, a great variety of glial cells were identified and their morphology was very precisely characterised.

The father of glia, Rudolf Virchow, invented the idea of nervous 'connective tissue' in 1846 , when he wrote "...this connective substance forms in the brain, in the spinal cord, and in the higher sensory nerves a sort of Nervenkitt (neuroglia), in which the nervous system elements are embedded" ([89]; quoted from [79]). The word 'glia' has a dubious origin, initially appearing in the ancient Greek texts in a form of ' $\gamma$ 入oto $\sigma$ ', which meant 'oily sediment' used for taking baths (Semonides, VII century B.C.), 'gum' (Herodotus, V century B.C.), or 'slippery, knavish person' in Aristophanes ( $\sim \mathrm{V}$ century B.C.) tragedies. The latter meaning remained in Modern Greek, where the word ' $\gamma \lambda \iota \mathrm{\iota} \delta\llcorner$ ' stands for a morally debased and filthy person. Virchow further elaborated the concept of glia in his classical book Die Cellularpathologie in ihrer Begründung auf physiologische and pathologische Gewebelehre [90]; for Virchow, neuroglia was a true connective tissue of a non-cellular nature.

The first description of neuroglial cell, the radial glial cell (which is now known as Müller cell) in the retina was made by Heinrich Müller in 1851. Several years later, these cells were also characterised by Max Schultze (for relevant referencing see historical reviews [41, 79]). Around 1865, Otto Deiters described the stellate cells in white and grey matter [26]. These cells closely resembled what we now know as astrocytes and in 1869, Jakob Henle has published the first image of cellular networks formed by stellate cells (i.e. astrocytes) in both grey and white matter of the spinal cord. Further discoveries in the field of the cellular origin of glial cells resulted from the efforts of many prominent histologists, in particular Camillo Golgi (1843-1926), Santiago Ramon y Cajal (1852-1934) and Pio Del Rio 


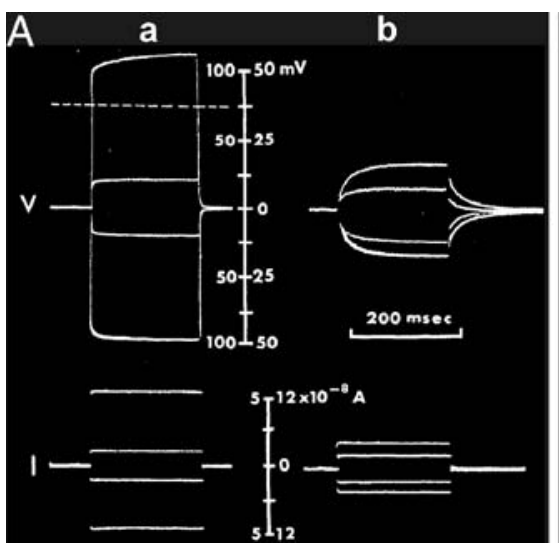

Fig. 1 First electrophysiological recordings from mammalian glial cells. a Passive behaviour of glial cell in the optic nerve of mud puppy, Nectarus. (a) A glial cell was penetrated with two electrodes, with tips located as close as possible; each electrode recorded resting potential of $75 \mathrm{mV}$. Square pulses of current passed through one electrode displace the membrane potential recorded by the second electrode. The two displacements are symmetrical in the hyperpolarising and depolarising direction. Dashed line indicates zero membrane potential. (b) Electrode tips were separated by $50 \mu \mathrm{m}$; current passed as in $(a)$, but potentials rise more slowly. When either

Hortega (1882-1945). Using a variety of microscopic techniques, Golgi and Ramon y Cajal discovered a wide diversity of glial cells in the brain, found the contacts formed between glial cells and blood vessels and observed cells located in closely aligned groups in between nerve fibres (this being the first observation of oligodendrocytes). Further advances in morphological characterisation of glia appeared after Golgi developed famous black (silver chromate) reaction, and Ramon y Cajal invented goldchloride sublimate staining technique, which significantly improved microscopic visualisation of cells (and neuroglial cells in particular) in brain tissues. Closer to the end of 19th century, Michael von Lenhossek proposed the term astrocyte (1893), which within the next two decades gained universal acceptance. The name 'oligodendrocyte' appeared slightly later, after Pio Del Rio-Hortega introduced silver carbonate staining technique, which selectively labelled these cells (1921). It was also Del Rio-Hortega who proposed the term 'microglia' to characterise the distinct cellular population of mesodermal origin; he was one of the first to understand that these cells can migrate and can act as phagocytes.

The main peripheral glial element, the Schwann cell, was named by Louis Antoine Ranvier (1871), after earlier discoveries of Robert Remak, who described the myelin sheath around peripheral nerve fibres (1838) and Theodor Schwann, who suggested that myelin sheath was a product of specialised cells (1839).

At the end of 19th century, several possible functional roles of glial cells were considered. Camillo Golgi, for

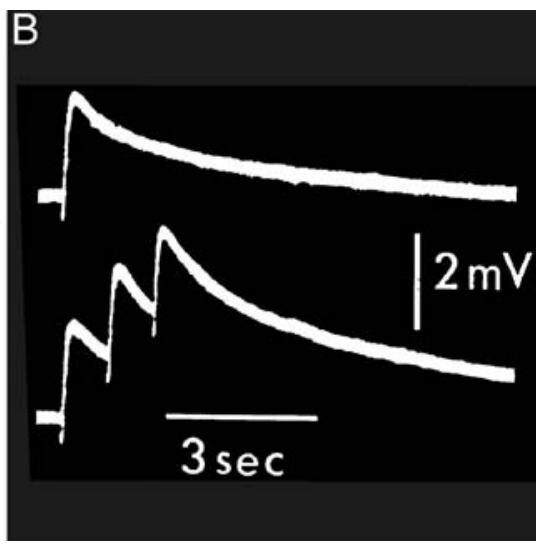

the stimulating or recording electrode was withdrawn from the cell, the electrotonic potentials disappeared. Lower races show current monitored during pulses. b Depolarisation of a glial cell produced by nerve impulses in the Nectarus optic nerve. Glial membrane potential recorded with an intracellular electrode was $86 \mathrm{mV}$. The isolated nerve was stimulated maximally a few millimeters from the site of microelectrode penetration. Upper trace shows glial depolarisation after a nerve volley. Lower trace shows glial depolarisation in response to three stimuli at $1 \mathrm{~s}$ interval; the glial depolarisation sum. Reproduced with permission from [50] (a) and [65] (b)

example, believed that glial cells are mainly responsible for feeding neurones, by virtue of their processes contacting both blood vessels and nerve cells. This theory was, however, opposed by Santiago Ramon y Cajal. Another theory (proposed by Carl Weigert) considered glial cells as mere structural elements of the brain, which filled space not occupied by neurones. Finally, Ramon-y-Cajal brother, Pedro, considered astrocytes as insulators, which prevented undesirable spread of neuronal impulses.

For the first time, the idea of active neuronal-glial interactions as a substrate for brain functions was voiced by Carl Ludwig Schleich (1859-1922) in 1894 in his book Schmerzlose Operationen [77]. Incidentally, this happened at the same year when the 'neuronal' doctrine was introduced by Sigmund Exner [29] and only 3 years after the term 'neurone' was coined by Wilhelm Gottfried von Waldeyer [93]. Schleich believed that glia and neurones both act as active cellular elements of the brain. He thought that glial cells represent fundamental inhibitory mechanism in the brain. According to Schleich, neuronal excitation is transmitted from neurone to neurone through intercellular gap; this inter-neuronal gap, surrounded by glial cells is the anatomical substrate for controlling excitation or inhibition in neural networks. The constantly changing volume of glial cell represents the mechanism for this control: swelling of glial cells inhibits neuronal communications, when glia shrinks, the impulse propagation is facilitated. The ideas of Schleich were never fully appreciated by a neuroscience community and from the beginning of 20th century glial cells were firmly believed to represent a 

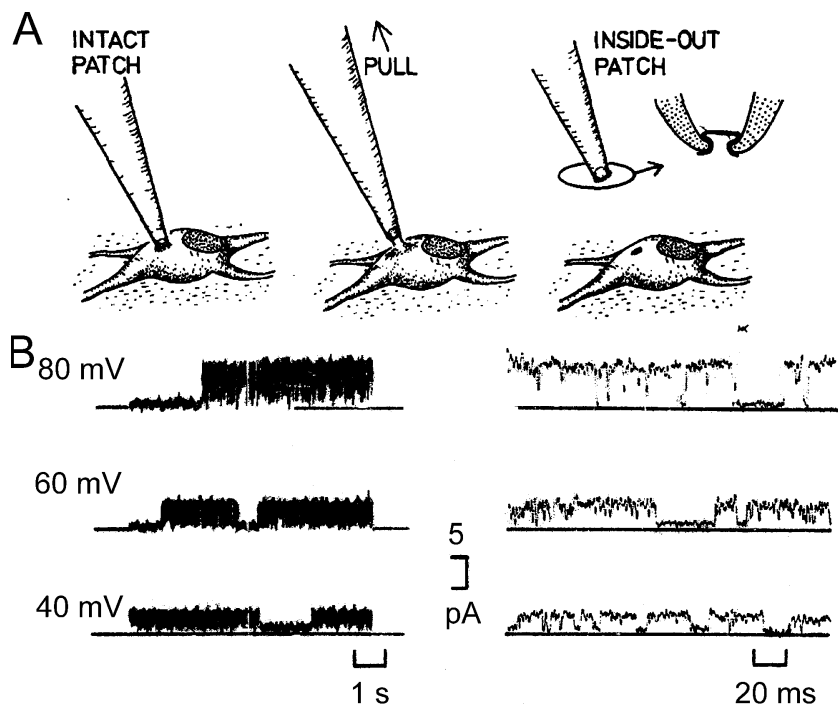

Fig. 2 First patch-clamp recordings of single potassium channels from cultured glial cells (oligodendrocytes). a Preparation of isolated membrane patches. b Single channel recordings from outside-out patch isolated from cultured oligodendrocyte at different membrane potentials and different time resolution. Channel conductance was $90 \mathrm{pS}$. Reproduced with permission from [40] (a) and [39] (b)

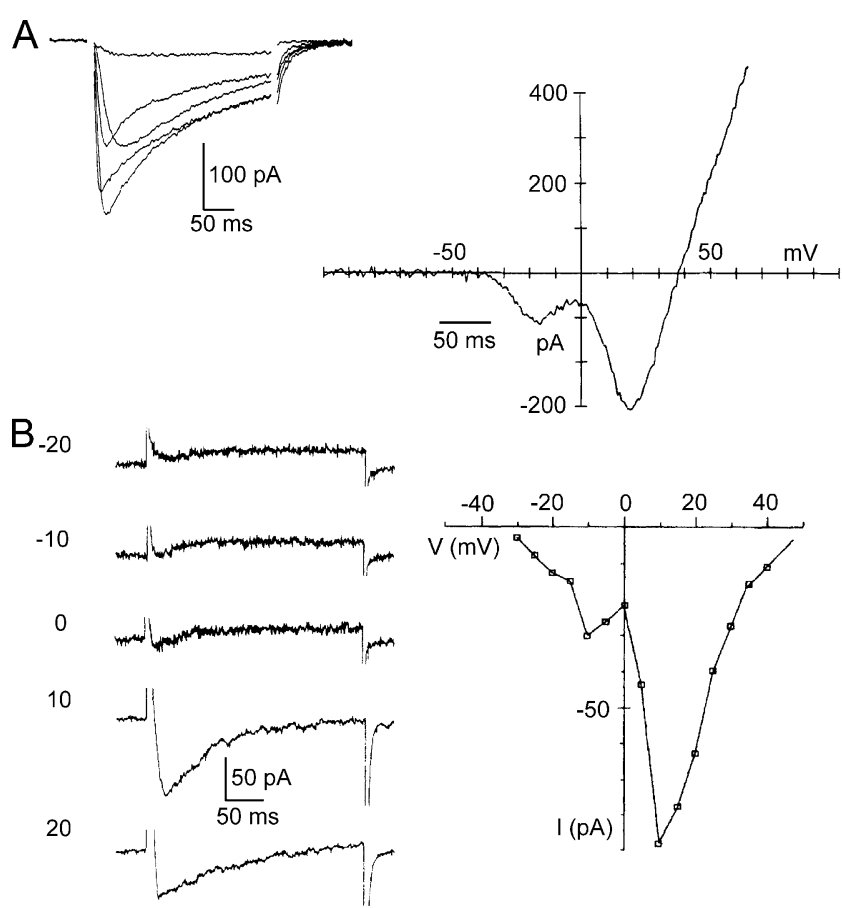

Fig. 3 Calcium currents in glial cells. a Voltage-sensitive calcium current in type 2 astrocyte in vitro. Left Family of calcium currents evoked by voltage steps from a prepulse potential of $-100 \mathrm{mV}$ to test steps ranging from -60 to $0 \mathrm{mV}$. Right The $\mathrm{I}-\mathrm{V}$ curve of calcium current measured in response to ramp stimulation from -100 to $100 \mathrm{mV}$ over $500 \mathrm{~ms}$. b Two types of $\mathrm{Ca}^{2+}$ currents recorded from cultured oligodendrocyte. The currents shown on the left were evoked by test depolarizations to different voltages (indicated near the traces) from the holding potential of $-75 \mathrm{mV}$. On the right, the I-V curves for total (LVA+HVA) calcium current is presented. Reproduced with permission from [5] (a) and [88] (b) supportive and passive element of the brain, completely devoid of any role in the integration and processing of information.

\section{Beginning of glial electrophysiology}

First electrophysiological recordings from glial cells were performed in 1964-1966 in the laboratory of Stefen Kuffler. In 1964, Kuffler and Potter made intracellular microelectrode recordings from leech glial cells [51], and in 1966 Kuffler, Nicholls and Orkand [50, 65] accomplished a detailed analysis of membrane potential in glial cells from the optic nerve of a vertebrate, a mud puppy (Fig. 1). Importantly, they demonstrated for the first time active neuronal-glial interactions by showing that stimulation of the optic nerve triggered depolarisation of the glia. Furthermore, they found that glial cells are electrically connected, and several years later, Milton Brightman and Tom Reese [19] identified gap junctions as structures connecting glial networks.

\section{The turn of the tide-identification of glial excitation}

The modern era of glial physiology was triggered by several important technical advances, which arrived almost simultaneously at the end of 1970 s to the beginning of 1980s. These were the patch-clamp, developed by Bert Sakmann and Ervin Neher in collaboration with Owen Hamill, Fred Sigworth and Alan Marty [33]; the florescent calcium indicators invented by Roger Tsien $[83,84]$ and the technique of preparation and maintenance of glial cell cultures [57, 58]. These techniques used alone or in combination were instrumental for many fundamental discoveries, which completely change our comprehension of the importance of glial cells in the nervous system.

Electrophysiological recordings from cultured glial cells (Figs. 2, 3 and 4) identified a wide variety of both voltageand ligand-gated currents. It turned out that glial cells are capable of generating the same types of voltage-gated currents (including, e.g. sodium and calcium currentsFig. 3) as neurones; main parameters of glial voltage-gated channels were very similar to those expressed in neurones [5-7, 13, 16, 39, 40, 54, 55, 80-88]. In 1984, intracellular microelectrode recordings from cultured astro- and oligodendroglia $[18,31,37,38]$ clearly demonstrated that glial cells can be depolarised by neurotransmitters such as glutamate, GABA and aspartate (Fig. 4); further patch clamp studies characterised functional glutamate and GABA receptors in macroglial cells $[17,81]$. Within the next decade, a huge variety of neurotransmitter receptors were discovered in cultured glial cells (see [72, 85-87] for 


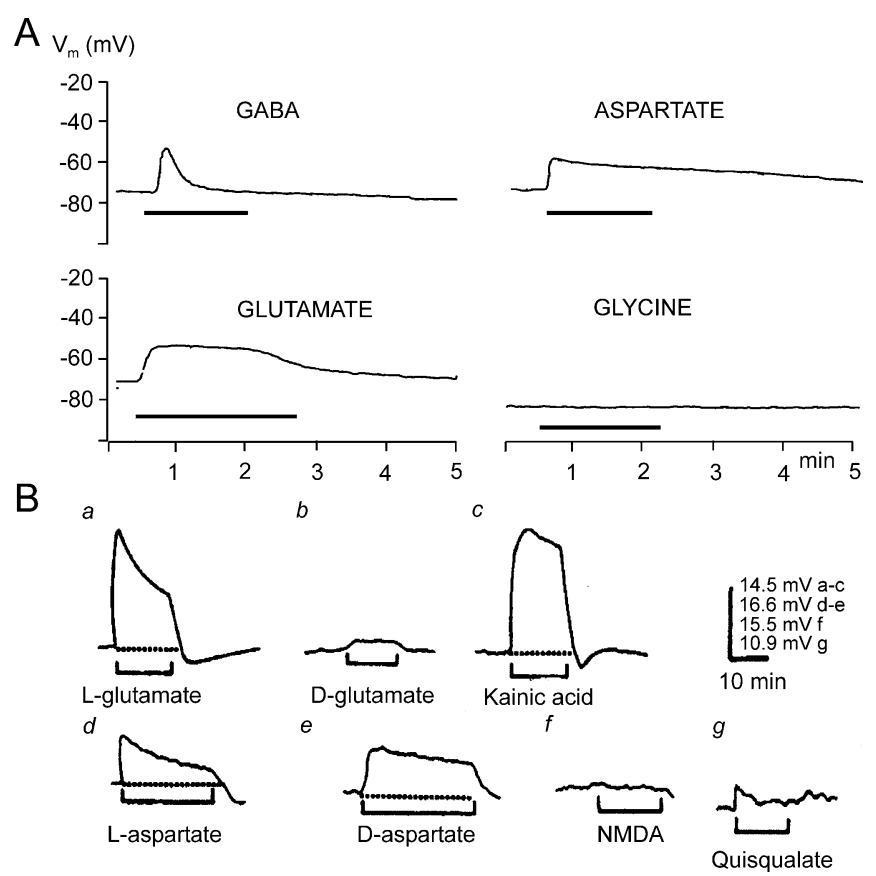

Fig. 4 Identification of functional neurotransmitter receptors in cultured astrocytes. a Microelectrode recordings from cultured astrocytes. The traces show effects of GABA, glutamate, aspartate and glycine all applied at a concentration of $1 \mathrm{mM}$. b Effects of excitatory amino acids on membrane potential of cultyred astrocytes. Amino acids were applied at a concentration of $10 \mathrm{mM}$. Membrane potentials of the cells, shown before addition of the amino acids, were $a-85 \mathrm{mV} ; b-87 \mathrm{mV} ; c-78 \mathrm{mV} ; d-56 \mathrm{mV} ; e-70 \mathrm{mV}$; $f-86 \mathrm{mV}$ and $g-64 \mathrm{mV}$. Reproduced with permission from [37] (a) and modified from [18] (b)

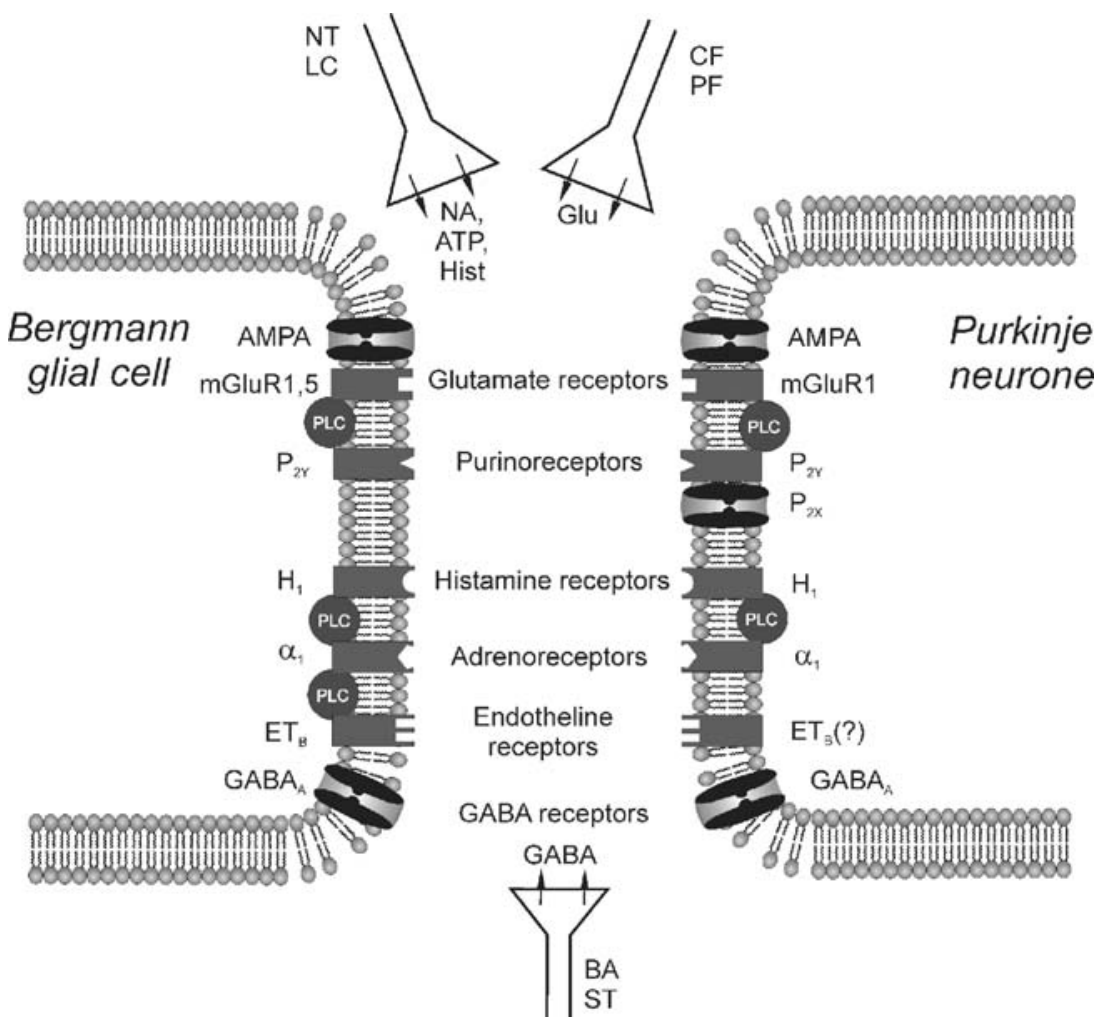

Fig. 5 Bergmann glial cell and its neighbour Purkinje neurone bear a similar set of neurotransmitter receptors. NT terminals from tuberomammillary nucleus of the posterior hypothalamus which carry histamine innervation of the cerebellar cortex; $L C$ terminals from locus coeruleus which utilize noradrenalin and ATP as neurotransmitters; $C F$ and $P F$ climbing and parallel fibers, respectively, major neurotransmitter glutamate; $B A$ and $S T$ basket and stellate cells which delivers GABA to Purkinje neurone layer. Reproduced with permission from [86] 

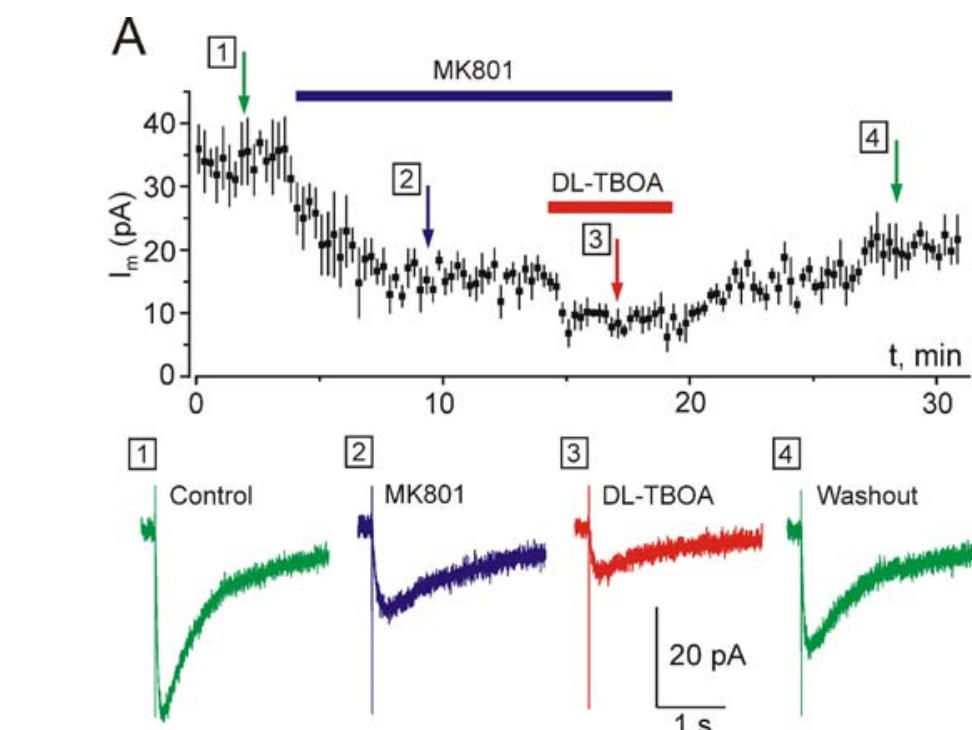

34
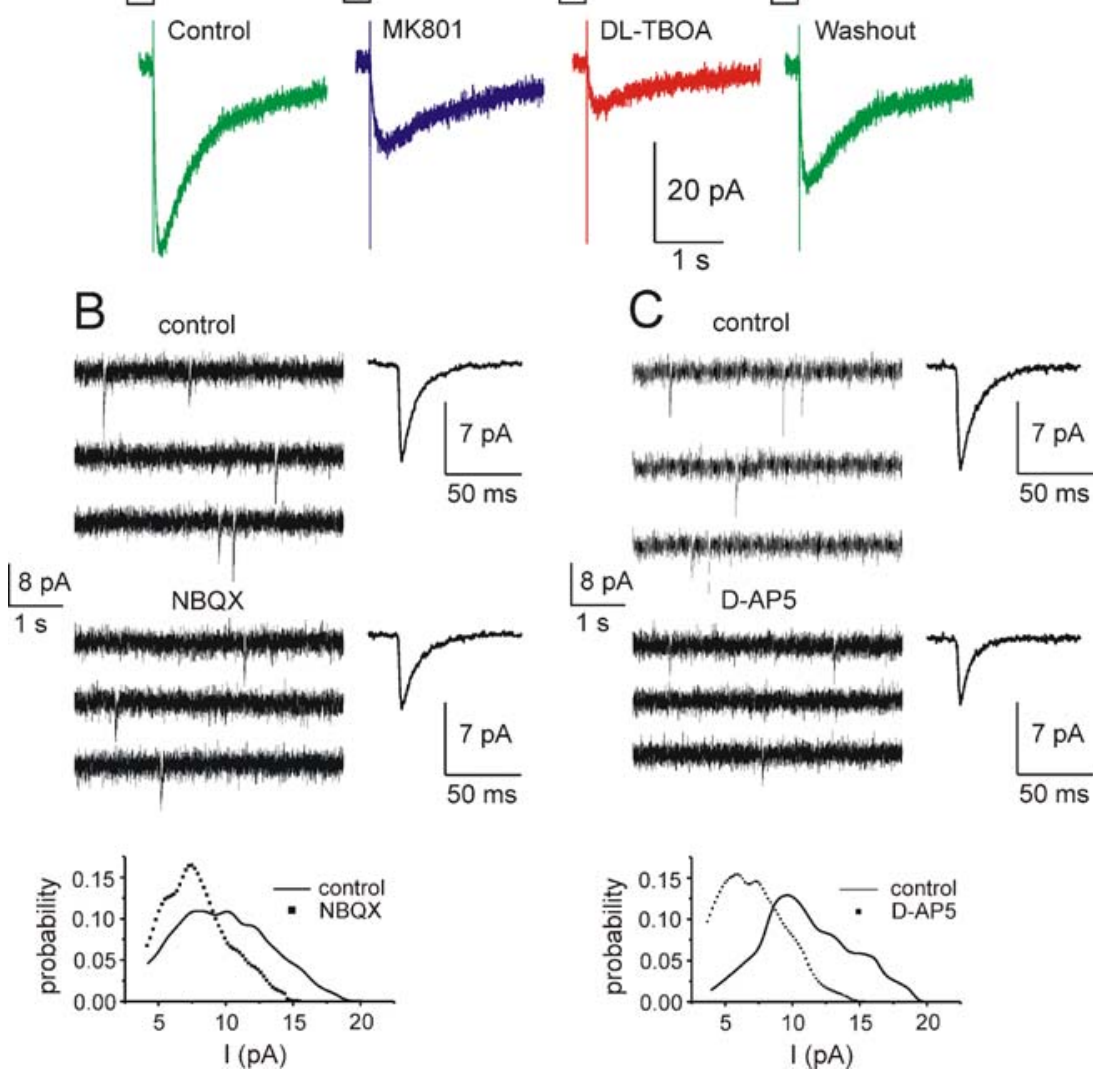

Fig. 6 Synaptic currents in cortical astrocytes. a Synaptic currents mediated by NMDA receptors in astrocytes. Astrocytes in layer II of the slice were identified by EGFP fluorescence and voltage-clamped; electrical stimulation of synaptic inputs was in layer IV. Synaptically evoked currents are inhibited by MK801 $(10 \mu \mathrm{M})$, and the residual current is partially blocked by DL-TBOA $(100 \mu \mathrm{M})$. Each point on the time graphs represents the mean \pm SEM for five EPSCs; illustrative EPSCs are shown below. b and $\mathbf{c}$ Miniature spontaneous excitatory currents in cortical astrocytes mediated by AMPA and NMDA glutamate receptors. b Representative whole-cell recordings in control and after application of NBQX $(30 \mu \mathrm{M})$. Right panels represent generalized waveform of spontaneous currents (average of 50 events).

review) initiating the hypothesis of active role of glia in the information exchange in the nervous system.

In parallel, the cytoplasmic calcium fluctuations were intensively studied in cultured glial cells loaded with fluorescent $\mathrm{Ca}^{2+}$ indicators. These studies have found that (1) stimulation of glia with neurotransmitters or hormones

Lower graph shows probability density function of spontaneous currents in control (solid line) and in the presence of NBQX (dots). c Representative whole-cell recordings from astrocytes in cortical slice in control and after application of D-AP5 $(30 \mu \mathrm{M})$. Right panels show generalized waveform of spontaneous currents (average of 50 events). Lower graph shows probability density function of spontaneous currents in control (solid line) and in the presence of D-AP5 (dots). All recordings were made at holding potential $-80 \mathrm{mV}$ in the presence of TTX $(1 \mu \mathrm{M})$, picrotoxin $(100 \mu \mathrm{M})$ and DL-TBOA $(100 \mu \mathrm{M})$. Note the significant decrease in the amplitude of spontaneous current as well as the leftward shift of amplitude distributions under action of glutamate receptor antagonists. Reproduced with permission from [52]

almost invariably resulted in generation of intracellular $\mathrm{Ca}^{2+}$ signals driven predominantly through the metabotropic route, which involved phospholipase $\mathrm{C} / \mathrm{InsP}_{3}$-evoked $\mathrm{Ca}^{2+}$ release from the endoplasmic reticulum $\mathrm{Ca}^{2+}$ store [30, 46, $72,85]$ and (2) that the $\mathrm{Ca}^{2+}$ signals triggered in one glial cell may travel though the syncytium formed within 
monolayers of cultured glial cells connected with gap junctions $[21-24,34]$. These findings led to formulation of hypothesis of special form of glial excitability, which is governed by $\mathrm{Ca}^{2+}$ release from the intracellular excitable media, represented by the membrane of the ER [86].

In 1989, another important technical step was made, when patch-clamp recordings were applied to the neurones in situ, in brain slices $[28,74]$. This technique was almost immediately applied to glial cells, thus eliminating the artefacts of cell culture (especially important for astrocytes, which demonstrated remarkable plasticity when being maintained in cell culture conditions) and permitting direct investigations of neuronal-glial interactions within their natural environment. These experiments (e.g. $[10-12,82])$ have confirmed that glial cells in situ express voltage-gated channels and neurotransmitter receptors, yet their distribution and regulation revealed important peculiarities. It turned out that in situ, the expression of many voltagegated channels is developmentally regulated; e.g. calcium and sodium channels are predominantly expressed in glial precursors and immature glial cells $[1,11,16]$. Second, it was realised that the expression of neurotransmitter receptors in situ is strictly controlled by the local environment. It was established that glial cells express receptors sensitive to neurotransmitters released in their vicinity; moreover, the receptors expressed in glial cell and in its neuronal neighbour have matching modalities [85, 86]. Initially, this relation was shown for Bergmann glial cells in the cerebellum (Fig. 5). These cells express receptors for noradrenalin, glutamate, GABA, histamine and ATP, i.e. the receptors activated by neurotransmitters released from terminals present in the Purkinje layer of cerebellum [43, 45, 47, 62, 63]; the closest neighbour of the Bergmann glial cell, the Purkinje neurone, also expressed receptors for these neurotransmitters [44]. Subsequently, similar matching relations between neuronal and glial receptor expression was found in the spinal cord, where both astrocytes and neurones possess glycine receptors acting as a main neurotransmitter in this region [42, 69].

\section{Neuronal-glial circuitry}

The experiments in situ also directly demonstrated the existence of neurones to glia signalling by showing that stimulation of axons or synaptic inputs trigger active responses in glial cells either in electrical form or in the form of $\mathrm{Ca}^{2+}$ signals. Stimulation of peripheral nerves triggered intracellular $\mathrm{Ca}^{2+}$ responses in both periaxonal and perisynaptic Schwann cells $[36,53,73]$; in the latter, $\mathrm{Ca}^{2+}$ signals resulted from the activation of glial receptors by synaptically released neurotransmitter. Similarly, stimulation of central axons induced $\mathrm{Ca}^{2+}$ responses in oligoden- drocytes (e.g. in optic nerve [49]). In the grey matter, neuronal activity also often triggered astroglial activation. In hippocampus and visual cortex, for example, electrical stimulation of synaptic afferents triggered both $\mathrm{Ca}^{2+}$ elevations $[25,68,71]$ and receptor-mediated ion current responses [35, 52] in astroglia (Fig. 6a). Most notably, electrophysiological recordings from identified cortical astrocytes detected spontaneous glutamate-mediated currents (Fig. 6b), very similar to neuronal 'miniature' EPSCs [52], suggesting that parts of glial membranes are located very close to the site of presynaptic release and astroglia is involved into the background neurotransmission.

In cerebellum, stimulation of parallel fibres induced a complex membrane current response in Bergmann glial cells (which intimately enwrap synapses formed by parallel fibres on Purkinje neurones), which was mediated by both activation of ionotropic AMPA-type glutamate receptors and activation of $\mathrm{Na}^{+}$-dependent glutamate transporters [22]. Most interestingly, the glial AMPA receptor-mediated responses show both short-term and long-term plasticity. The former is manifested by prominent paired-pulse facilitation [8], whereas the latter appears in a form of long-term depression of synaptically induced glial responses following low-frequency repetitive stimulation of parallel fibres [9]. Bergmann glial cells also demonstrated clear elementary 'postsynaptic' currents in response to quantal release of glutamate from presynaptic terminals [56], suggesting very close apposition of glial and presynaptic membranes. Electrical stimulation of parallel fibres also triggered cytoplasmic calcium responses in Bergmann glia; these calcium responses were very much localised, being limited to a small compartments within glial cell processes [32]. It is interesting to note that the size of these compartments, where local $\mathrm{Ca}^{2+}$ signals occurred, was similar to morphologically distinct appendage-like structures, protruding from the main process and enwrapping a cluster of synapses formed by parallel fibres. This high compartmentalisation of synaptically induced glial $\mathrm{Ca}^{2+}$ responses can be important for spatial discrimination of the incoming signals.

Further experiments revealed yet another important fact: glial cells can signal back to neurones. This type of glia to neurone signalling was detected in both glial-neuronal cocultures and in acutely isolated brain slices. Using the in vitro model, several groups have demonstrated that stimulation of astrocytes evoked direct excitation of nearby neurones [34, 75] and affected spontaneous [4] and evoked [2] postsynaptic currents. Inhibition of astroglial calcium signals (either by intracellular administration of BAPTA or by suppression of $\mathrm{ER} \mathrm{Ca}^{2+}$ release by thapsigargin) eliminated all neuronal responses. In acute slices, activation of glia was also shown to trigger direct neuronal responses. Spontaneous $\mathrm{Ca}^{2+}$ oscillations in astrocytes, for example, 
excited neighbouring neurones in hippocampus, cortex and thalamus $[66,68]$. When astrocytes in CA1 hippocampal slices were activated by prostaglandin E2, adjacent neurones generated $\mathrm{Ca}^{2+}$ signals; this action was mediated through glutamate receptors [14]. Activation of hippocampal astrocytes was also reported to produce tonic suppression of synaptic transmission; this inhibition was mediated by adenosine accumulated after the release of ATP from the astroglia [67].

Quite recently, it also became clear that the main mechanism of astroglial to neuronal signalling involves secretion of classical neurotransmitters, such as glutamate or ATP from the glial cells; this secretion can occur through several independent routes, most importantly though regulated exocytosis. It is interesting to note that the first indication that glial cells (e.g. Schwann cells and astrocytes) are capable of secreting neurotransmitters such as acetylcholine and GABA were obtained already from mid1970s [27, 59, 78], although these data were not somehow generally acknowledged. In recent years, however, the concept of neurotransmitters release from glia gained firm support. Glial cells were found to contain secretory vesicles endowed with glutamate transporters and reach in glutamate; it was also shown that astroglial cells express numerous proteins responsible for exocytotic vesicles fusion, including cellubrevin (VAMP3), SNAP23, complexin 2, Munch 18a and synaptotagmin IV [15, 61, 92, 94]. Finally, the $\mathrm{Ca}^{2+}$-induced exocytosis of glutamate from astrocytes was directly identified by total internal reflection fluorescence imaging [15], and exocytotic fusion after $\left[\mathrm{Ca}^{2+}\right]_{i}$ signals was measured by membrane capacitance recordings [48]. Besides glutamate and ATP astrocytes are able to release several other 'glio' transmitters, most notably taurine [20], aspartate [60] and D-serine [64, 76]. All these transmitters can be secreted either by exocytosis or through membrane channels, such as volume-sensitive $\mathrm{Cl}^{-}$channels or pores associated with activation of $\mathrm{P} 2 \mathrm{X}_{7}$ purinoreceptors, or indeed through reversal of neurotransmitter transporters.

All these discoveries led to a complete rethinking of the role and place of neuroglia in brain circuits and initiated an appearance of a concept of a 'tripartite' synapse; this concept regards glial cell as legitimate part of the synapse, which is built from three functionally important compartments: presynaptic, postsynaptic and glial [3, 70, 91].

\section{Brain integration as a function of neuronal-glial networking: can neuronal doctrine hold?}

Our understanding of glial function changed dramatically over the last 15 years. This change concerns not only the physiology of glia but also the whole concept of the way how the brain is organised and how the development, life and death of neural circuits are controlled. There is a compelling evidence demonstrating that the radial glial cells serve as pluripotent neural progenitors and the cells with astroglial phenotype are the brain stem elements underlying adult neurogenesis. The mature astroglia defines the microarchitecture of the grey matter by dividing it into separate units, where the astrocyte rules over all neuronal membranes and synaptic contacts within this clearly defined territory. Within this territory, astrocytes control almost everything from regulating birth, maintenance and elimination of synapses to providing active neurones with energy substrates and linking neurones with local microcirculation. Although clearly delineated, the astrocytic domains are tightly integrated into the syncytium by gap junctions connecting the terminal processes of glial cells. This syncytial structure permits long-range signalling and intercellular exchange of metabolites and second messengers. At the same time, astrocytes are fully capable of extracellular signalling by virtue of 'glio' transmitters secreted in highly regulated fashion. These multiple signalling abilities, which include both intra-and extracellular routes, can potentially be very important for integrative processes within astroglial networks. Finally, the failure of astrocytes to perform their duty invariably results in neuronal death, and many types of brain pathology, from stroke to Alzheimer disease may be primarily glial diseases.

All in all, glial cells weave the canvass on top of which neurones perform their rapid signalling. The extremely elaborated panglial syncytium resembles the 'reticular theory' of brain organization so much championed by Golgi and Kolliker, which now can be safely reconciled with 'neuronal' theory, as both internally connected glial syncytium and discreet neuronal networks peacefully coexist within the brain. Shall we anticipate even more exciting discoveries which eventually can challenge the role of neurones as sole origins of cognition? Can neuronal doctrine withstand the challenge from glial cells? These questions are still open. Nonetheless, after 20 years of patching the glia, we already elevated these cells from a mere 'nerve putty' to an active element of the brain circuitry.

Acknowledgements The author's research was supported by The Wellcome Trust, The Alzheimer Research Trust, NIH, Royal Society and INTAS.

\section{References}

1. Akopian G, Kressin K, Derouiche A, Steinhauser C (1996) Identified glial cells in the early postnatal mouse hippocampus display different types of Ca2+ currents. Glia 17:181-194 
2. Araque A, Parpura V, Sanzgiri RP, Haydon PG (1998) Glutamatedependent astrocyte modulation of synaptic transmission between cultured hippocampal neurons. Eur J Neurosci 10:2129-2142

3. Araque A, Parpura V, Sanzgiri RP, Haydon PG (1999) Tripartite synapses: glia, the unacknowledged partner. Trends Neurosci 22:208-215

4. Araque A, Sanzgiri RP, Parpura V, Haydon PG (1998) Calcium elevation in astrocytes causes an NMDA receptor-dependent increase in the frequency of miniature synaptic currents in cultured hippocampal neurons. J Neurosci 18:6822-6829

5. Barres BA, Chun LL, Corey DP (1988) Ion channel expression by white matter glia: I Type 2 astrocytes and oligodendrocytes. Glia $1: 10-30$

6. Barres BA, Koroshetz WJ, Chun LL, Corey DP (1990) Ion channel expression by white matter glia: the type-1 astrocyte. Neuron 5:27-544

7. Barres BA, Koroshetz WJ, Swartz KJ, Chun LL, Corey DP (1990) Ion channel expression by white matter glia: the O-2A glial progenitor cell. Neuron 4:507-524

8. Bellamy TC, Ogden D (2005) Short-term plasticity of Bergmann glial cell extrasynaptic currents during parallel fiber stimulation in rat cerebellum. Glia 52:325-335

9. Bellamy TC, Ogden D (2006) Long-term depression of neuron to glial signalling in rat cerebellar cortex. Eur J Neurosci 23:581-586

10. Berger T, Schnitzer J, Kettenmann H (1991) Developmental changes in the membrane current pattern, $\mathrm{K}+$ buffer capacity, and morphology of glial cells in the corpus callosum slice. J Neurosci 11:3008-3024

11. Berger T, Schnitzer J, Orkand PM, Kettenmann H (1992) Sodium and calcium currents in glial cells of the mouse corpus callosum slice. Eur J Neurosci 4:1271-1284

12. Berger T, Walz W, Schnitzer J, Kettenmann H (1992) GABA- and glutamate-activated currents in glial cells of the mouse corpus callosum slice. J Neurosci Res 31:21-27

13. Bevan S, Chiu SY, Gray PT, Ritchie JM (1985) The presence of voltage-gated sodium, potassium and chloride channels in rat cultured astrocytes. Proc R Soc Lond B Biol Sci 225:299-313

14. Bezzi P, Carmignoto G, Pasti L, Vesce S, Rossi D, Rizzini BL, Pozzan T, Volterra A (1998) Prostaglandins stimulate calciumdependent glutamate release in astrocytes. Nature 391:281-285

15. Bezzi P, Gundersen V, Galbete JL, Seifert G, Steinhauser C, Pilati E, Volterra A (2004) Astrocytes contain a vesicular compartment that is competent for regulated exocytosis of glutamate. Nat Neurosci 7:613-620

16. Blankenfeld Gv G, Verkhratsky AN, Kettenmann H (1992) Ca2+ channel expression in the oligodendrocyte lineage. Eur J Neurosci 4:1035-1048

17. Bormann J, Kettenmann H (1988) Patch-clamp study of gammaaminobutyric acid receptor $\mathrm{Cl}-$ channels in cultured astrocytes. Proc Natl Acad Sci USA 85:9336-9340

18. Bowman CL, Kimelberg HK (1984) Excitatory amino acids directly depolarize rat brain astrocytes in primary culture. Nature 311:656-659

19. Brightman MW, Reese TS (1969) Junctions between intimately apposed cell membranes in the vertebrate brain. J Cell Biol 40:648-677

20. Cardin V, Lezama R, Torres-Marquez ME, Pasantes-Morales H (2003) Potentiation of the osmosensitive taurine release and cell volume regulation by cytosolic $\mathrm{Ca} 2+$ rise in cultured cerebellar astrocytes. Glia 44:119-128

21. Charles AC, Merrill JE, Dirksen ER, Sanderson MJ (1991) Intercellular signaling in glial cells: calcium waves and oscillations in response to mechanical stimulation and glutamate. Neuron 6:983-992
22. Clark BA, Barbour B (1997) Currents evoked in Bergmann glial cells by parallel fibre stimulation in rat cerebellar slices. J Physiol 502:335-350

23. Cornell-Bell AH, Finkbeiner SM (1991) Ca2+ waves in astrocytes. Cell Calcium 12:185-204

24. Cornell-Bell AH, Finkbeiner SM, Cooper MS, Smith SJ (1990) Glutamate induces calcium waves in cultured astrocytes: longrange glial signaling. Science 247:470-473

25. Dani JW, Chernjavsky A, Smith SJ (1992) Neuronal activity triggers calcium waves in hippocampal astrocyte networks. Neuron 8:429-440

26. Deiters O (1865) Untersuchungen über Gehirn und Rückenmark des Menschen und der Säugethiere. Vieweg, Braunschweig

27. Dennis MJ, Miledi R (1974) Electrically induced release of acetylcholine from denervated Schwann cells. J Physiol 237:431452

28. Edwards FA, Konnerth A, Sakmann B, Takahashi T (1989) A thin slice preparation for patch clamp recordings from neurones of the mammalian central nervous system. Pflugers Arch 414:600-612

29. Exner S (1894) Entwurf zur physiologischen Erklärung der Psychischen Erscheinungen. Deiticke, Leipzig/Vienna

30. Finkbeiner SM (1993) Glial calcium. Glia 9:83-104

31. Gilbert P, Kettenmann H, Schachner M (1984) gamma-Aminobutyric acid directly depolarizes cultured oligodendrocytes. J Neurosci 4:561-569

32. Grosche J, Matyash V, Moller T, Verkhratsky A, Reichenbach A, Kettenmann H (1999) Microdomains for neuron-glia interaction: parallel fiber signaling to Bergmann glial cells. Nat Neurosci 2:139-143

33. Hamill OP, Marty A, Neher E, Sakmann B, Sigworth FJ (1981) Improved patch-clamp techniques for high-resolution current recording from cells and cell-free membrane patches. Pflugers Arch 391:85-100

34. Hassinger TD, Atkinson PB, Strecker GJ, Whalen LR, Dudek FE, Kossel AH, Kater SB (1995) Evidence for glutamate-mediated activation of hippocampal neurons by glial calcium waves. J Neurobiol 28:159-170

35. Jabs R, Pivneva T, Huttmann K, Wyczynski A, Nolte C, Kettenmann H, Steinhauser C (2005) Synaptic transmission onto hippocampal glial cells with hGFAP promoter activity. J Cell Sci 118:3791-3803

36. Jahromi BS, Robitaille R, Charlton MP (1992) Transmitter release increases intracellular calcium in perisynaptic Schwann cells in situ. Neuron 8:1069-1077

37. Kettenmann H, Backus KH, Schachner M (1984) Aspartate, glutamate and gamma-aminobutyric acid depolarize cultured astrocytes. Neurosci Lett 52:25-29

38. Kettenmann H, Gilbert P, Schachner M (1984) Depolarization of cultured oligodendrocytes by glutamate and GABA. Neurosci Lett 47:271-276

39. Kettenmann H, Okland RK, Lux HD, Schachner M (1982) Single potassium channel currents in cultured mouse oligodendrocytes. Neurosci Lett 32:41-46

40. Kettenmann H, Orkand RK, Lux HD (1984) Some properties of single potassium channels in cultured oligodendrocytes. Pflugers Arch 400:215-221

41. Kettenmann H, Ransom BR (2005) The concept of neuroglia: a historical perspective. In: Kettenmann H, Ransom BR (eds) Neuroglia. OUP, Oxford, pp 1-16

42. Kirchhoff F, Mulhardt C, Pastor A, Becker CM, Kettenmann H (1996) Expression of glycine receptor subunits in glial cells of the rat spinal cord. J Neurochem 66:1383-1390

43. Kirischuk S, Kirchhoff F, Matyash V, Kettenmann H, Verkhratsky A (1999) Glutamate-triggered calcium signalling in mouse bergmann glial cells in situ: role of inositol-1,4,5-trisphos- 
phate-mediated intracellular calcium release. Neuroscience 92:1051-1059

44. Kirischuk S, Matiash V, Kulik A, Voitenko N, Kostyuk P, Verkhratsky A (1996) Activation of P2-purino-, a1-adreno and H1-histamine receptors triggers cytoplasmic calcium signalling in cerebellar Purkinje neurons. Neuroscience 73:643-647

45. Kirischuk S, Moller T, Voitenko N, Kettenmann H, Verkhratsky A (1995) ATP-induced cytoplasmic calcium mobilization in Bergmann glial cells. J Neurosci 15:7861-7871

46. Kirischuk S, Scherer J, Kettenmann H, Verkhratsky A (1995) Activation of $\mathrm{P} 2$-purinoreceptors triggered $\mathrm{Ca} 2+$ release from InsP3-sensitive internal stores in mammalian oligodendrocytes. J Physiol 483:41-57

47. Kirischuk S, Tuschick S, Verkhratsky A, Kettenmann H (1996) Calcium signalling in mouse Bergmann glial cells mediated by alpha1-adrenoreceptors and $\mathrm{H} 1$ histamine receptors. Eur J Neurosci 8:1198-1208

48. Kreft M, Stenovec M, Rupnik M, Grilc S, Krzan M, Potokar M, Pangrsic T, Haydon PG, Zorec R (2004) Properties of Ca2+dependent exocytosis in cultured astrocytes. Glia 46:437-445

49. Kriegler S, Chiu SY (1993) Calcium signaling of glial cells along mammalian axons. J Neurosci 13:4229-4245

50. Kuffler SW, Nicholls JG, Orkand RK (1966) Physiological properties of glial cells in the central nervous system of amphibia. J Neurophysiol 29:768-787

51. Kuffler SW, Potter DD (1964) Glia in the leech central nervous system: Physiological properties and neuron-glia relationship. J Neurophysiol 27:290-320

52. Lalo U, Pankratov Y, Kirchhoff F, North RA, Verkhratsky A (2006) NMDA receptors mediate neuron-to-glia signaling in mouse cortical astrocytes. J Neurosci 26:2673-2683

53. Lev-Ram V, Ellisman MH (1995) Axonal activation-induced calcium transients in myelinating Schwann cells, sources, and mechanisms. J Neurosci 15:2628-2637

54. MacVicar BA (1984) Voltage-dependent calcium channels in glial cells. Science 226:1345-1347

55. MacVicar BA, Tse FW (1988) Norepinephrine and cyclic adenosine $3^{\prime}: 5^{\prime}$-cyclic monophosphate enhance a nifedipinesensitive calcium current in cultured rat astrocytes. Glia 1:359365

56. Matsui K, Jahr CE, Rubio ME (2005) High-concentration rapid transients of glutamate mediate neural-glial communication via ectopic release. J Neurosci 25:7538-7547

57. McCarthy KD, de Vellis J (1980) Preparation of separate astroglial and oligodendroglial cell cultures from rat cerebral tissue. J Cell Biol 85:890-902

58. McCarthy KD, Partlow LM (1976) Preparation of pure neuronal and non-neuronal cultures from embryonic chick sympathetic ganglia: a new method based on both differential cell adhesiveness and the formation of homotypic neuronal aggregates. Brain Res 114:391-414

59. Minchin MC, Iversen LL (1974) Release of 3H gamma-aminobutyric acid from glial cells in rat dorsal root ganglia. J Neurochem 23:533-540

60. Mongin AA, Kimelberg HK (2005) ATP regulates anion channelmediated organic osmolyte release from cultured rat astrocytes via multiple Ca2+-sensitive mechanisms. Am J Physiol Cell Physiol 288:C204-C213

61. Montana V, Ni Y, Sunjara V, Hua X, Parpura V (2004) Vesicular glutamate transporter-dependent glutamate release from astrocytes. J Neurosci 24:2633-2642

62. Muller T, Fritschy JM, Grosche J, Pratt GD, Mohler H, Kettenmann H (1994) Developmental regulation of voltage-gated $\mathrm{K}+$ channel and GABAA receptor expression in Bergmann glial cells. J Neurosci 14:2503-2514
63. Muller T, Moller T, Berger T, Schnitzer J, Kettenmann H (1992) Calcium entry through kainate receptors and resulting potassiumchannel blockade in Bergmann glial cells. Science 256:1563-1566

64. Mustafa AK, Kim PM, Snyder SH (2004) D-Serine as a putative glial neurotransmitter. Neuron Glia Biol 1:275-281

65. Orkand RK, Nicholls JG, Kuffler SW (1966) Effect of nerve impulses on the membrane potential of glial cells in the central nervous system of amphibia. J Neurophysiol 29:788-806

66. Parri HR, Gould TM, Crunelli V (2001) Spontaneous astrocytic $\mathrm{Ca} 2+$ oscillations in situ drive NMDAR-mediated neuronal excitation. Nat Neurosci 4:803-812

67. Pascual O, Casper KB, Kubera C, Zhang J, Revilla-Sanchez R, Sul JY, Takano H, Moss SJ, McCarthy K, Haydon PG (2005) Astrocytic purinergic signaling coordinates synaptic networks. Science 310:113-116

68. Pasti L, Volterra A, Pozzan T, Carmignoto G (1997) Intracellular calcium oscillations in astrocytes: a highly plastic, bidirectional form of communication between neurons and astrocytes in situ. J Neurosci 17:7817-7830

69. Pastor A, Chvatal A, Sykova E, Kettenmann H (1995) Glycineand GABA-activated currents in identified glial cells of the developing rat spinal cord slice. Eur J Neurosci 7:1188-1198

70. Perea G, Araque A (2005) Glial calcium signaling and neuron-glia communication. Cell Calcium 38:375-382

71. Porter JT, McCarthy KD (1996) Hippocampal astrocytes in situ respond to glutamate released from synaptic terminals. J Neurosci 16:5073-5081

72. Porter JT, McCarthy KD (1997) Astrocytic neurotransmitter receptors in situ and in vivo. Prog Neurobiol 51:439-455

73. Reist NE, Smith SJ (1992) Neurally evoked calcium transients in terminal Schwann cells at the neuromuscular junction. Proc Natl Acad Sci USA 89:7625-7629

74. Sakmann B, Edwards F, Konnerth A, Takahashi T (1989) Patch clamp techniques used for studying synaptic transmission in slices of mammalian brain. Q J Exp Physiol 74:1107-1118

75. Sanzgiri RP, Araque A, Haydon PG (1999) Prostaglandin E2 stimulates glutamate receptor-dependent astrocyte neuromodulation in cultured hippocampal cells. J Neurobiol 41:221-229

76. Schell MJ, Molliver ME, Snyder SH (1995) D-serine, an endogenous synaptic modulator: localization to astrocytes and glutamate-stimulated release. Proc Natl Acad Sci USA 92: 3948-3952

77. Schleich CL (1894) Schmerzlose Operationen: Örtliche Betäubung mit indiffrenten Flüssigkeiten. Psychophysik des natürlichen und künstlichen Schlafes. Springer, Berlin Heidelberg New York

78. Shain W, Madelian V, Martin DL, Kimelberg HK, Perrone M, Lepore R (1986) Activation of beta-adrenergic receptors stimulates release of an inhibitory transmitter from astrocytes. J Neurochem 46:1298-1303

79. Somjen GG (1988) Nervenkitt: notes on the history of the concept of neuroglia. Glia 1:2-9

80. Sontheimer H, Kettenmann H (1988) Heterogeneity of potassium currents in cultured oligodendrocytes. Glia 1:415-420

81. Sontheimer H, Kettenmann H, Backus KH, Schachner M (1988) Glutamate opens $\mathrm{Na}+\mathrm{K}+$ channels in cultured astrocytes. Glia $1: 328-336$

82. Steinhauser C, Berger T, Frotscher M, Kettenmann H (1992) Heterogeneity in the membrane current pattern of identified glial cells in the hippocampal slice. Eur J Neurosci 4:472-484

83. Tsien RY (1980) New calcium indicators and buffers with high selectivity against magnesium and protons: design, synthesis, and properties of prototype structures. Biochemistry 19:2396-2404

84. Tsien RY (1981) A non-disruptive technique for loading calcium buffers and indicators into cells. Nature 290:527-528 
85. Verkhratsky A, Kettenmann H (1996) Calcium signalling in glial cells. Trends Neurosci 19:346-352

86. Verkhratsky A, Orkand RK, Kettenmann H (1998) Glial calcium: homeostasis and signaling function. Physiol Rev 78:99-141

87. Verkhratsky A, Steinhauser C (2000) Ion channels in glial cells. Brain Res Brain Res Rev 32:380-412

88. Verkhratsky AN, Trotter J, Kettenmann H (1990) Cultured glial precursor cells from mouse cortex express two types of calcium currents. Neurosci Lett 112:194-198

89. Virchow R (1846) Uber das granulierte Ansehen der Wandungen der Gehirnventrikel. Allg Zsch Psychiat 3:242-250

90. Virchow R (1858) Die Cellularpathologie in ihrer Begründung auf physiologische and pathologische Gewebelehre. Zwanzig Vorlesungen gehalten während der Monate Februar, März und April
1858 im pathologischen Institut zu Berlin. August Hirschwald, Berlin

91. Volterra A, Haydon P, Magistretti P (2002) Glia in synaptic transmission. Oxford University Press, Oxford

92. Volterra A, Meldolesi J (2005) Astrocytes, from brain glue to communication elements: the revolution continues. Nat Rev Neurosci 6:626-640

93. Waldeyer von HWG (1891) Über einige neuere Forschungen im Gebiete der Anatomie des Centralnervensystems. Dtsch Med Wochenschr 44:1-44

94. Zhang Q, Pangrsic T, Kreft M, Krzan M, Li N, Sul JY, Halassa M, Van Bockstaele E, Zorec R, Haydon PG (2004) Fusionrelated release of glutamate from astrocytes. J Biol Chem 279:12724-12733 